\title{
Monitoring the side effects with DSC caused by cyclophosphamide treatment
}

\author{
Péter Farkas ${ }^{1}$ - Franciska Könczöl $\left.\right|^{2}$. Dénes Lőrinczy ${ }^{3}$ (])
}

Received: 15 July 2019 / Accepted: 14 November 2019 / Published online: 21 November 2019

(c) The Author(s) 2019

\begin{abstract}
Polyneuropathy is defined as a simultaneous malfunction of several peripheral nerves, which could be a side effect of a cancer therapy (using cyclophosphamide) as well. In the daily use, it is very important to know the kinetics and metabolism of anticancer drugs because this way we can estimate their undesirable consequences to avoid the unwanted complications. Nowadays, the application of DSC in diagnosis of different diseases using blood compounds is increasing; therefore, the purpose of recent study was to introduce at the first time the DSC in the detection of cyclophosphamide-induced changes in plasma and red blood cells in case of an experimental animal model. Guinea pigs (Cavia porcellus, $n=60$, in 12 different groups) underwent to cyclophosphamide treatment administrated intraperitoneally with the dose comparable to the human dosage. At the end of treatments, the animals were euthanized, and the experimental samples (plasma end red blood cells) were analyzed by a SETARAM Micro DSC-II calorimeter. The denaturation temperatures and the calorimetric enthalpies were calculated from the heat flow curves. Our results exhibited a dose-dependent difference between thermal parameters of untreated and treated samples, demonstrating that DSC is applicable in this field too. After deconvolution of DSC scans, the changes could be assigned to the attacked compounds. Recently published papers call the attention for this technique more frequently in the medical diagnosis because this way from small amount of sample very quickly and economically possible to detect and predict the expected and unwanted side effects of chemotherapeutic agents.
\end{abstract}

Keywords Polyneuropathia $\cdot$ Cyclophosphamide $\cdot$ Blood plasma and red blood cell $\cdot$ DSC

\section{Introduction}

The cyclophosphamide is a widely used anticancer drug and is on the most important drugs' list of WHO. It is widely used in different treatments (e.g., immunological diseases, various cancers and organ transplantations) [1]. Besides some beneficial effects, it has many short- and long-term side effects [2-5]. Its kinetics and metabolism has a big variability; this way is rather difficult to predict its therapeutic and side effects. We have increasing demand in the daily

Dénes Lőrinczy

denes.lorinczy@aok.pte.hu

1 Clinics of Radiology, University of Pécs, Szigeti str. 12, Pécs 7624, Hungary

2 Institute of Forensic Medicine, University of Pécs, Szigeti str. 12, Pécs 7624, Hungary

3 Institute of Biophysics School of Medicine, University of Pécs, Szigeti str. 12, Pécs 7624, Hungary practice for an efficient and useful method to measure its amount in blood plasma or other blood compound [6-8].

Plasma is a transporter of substances that are important to the body. It contains roughly $90 \%$ water, and many types of plasma proteins. Plasma proteins are more than 200 with function, but generally, we detect only six main fractions: albumin, $\alpha 1, \alpha 2, \beta$ globulin, $\gamma$-globulin and fibrinogen. Proteins can influence the fluid distribution acid-base balance and immune function in the body. Drugs and other substances administrated intravenously into blood path distribute uniformly in intravascular space in $5 \mathrm{~min}$ [9]. The amount of cyclophosphamide in plasma influences the expected therapeutic and side effects as well as the complications too. Its metabolism shows large individual, partly genetically determined variability and it can be under the influence of co-diseases or other associated treatments; therefore, it may alter in the function of time [6]. Joy et al. [10] demonstrated alteration in its pharmacokinetics effect (e.g., in case of glomerulonephritis and tumor). 
In the last year, numerous studies were published investigating blood plasma with DSC. They proved that thermal analysis is a very sensitive and informative technique to detect alterations in plasma caused by different diseases or treatments [11-23]. When cyclophosphamide will bind to the blood cells, some alterations should go on in the cell membrane, and this should appear comparing DSC scans of treated and reference blood cells.

It is the reason that besides plasma, we examined red blood cells too. The red blood cells are responsible for gas transport and acid-base balance in the body [9]. In the blood stream, the cyclophosphamide is transported in dissolved form, and about $20 \%$ of cases, it is bounded to plasma proteins [24]. The cytotoxic effect of cyclophosphamide can make a reduction in the number of red blood cell.

Our aim is to determine where to attack cyclophosphamide in plasma and red blood cells using DSC. It will help us to check the role of drug concentration, and in this way, we can apply a proper dosage and the administration protocol in case of patients.

\section{Materials and methods}

\section{Animal samples}

The experimental animals (Cavia porcellus) were treated intraperitoneally - as it is usual in case of drug administration for pets [25] - to 12 different dosing schemes $(n=60$, $n=5$ /group, see [7]). The dose of cyclophosphamide was normalized to the guinea pigs' mass according to the human protocols (150 $\mathrm{mg} \mathrm{kg}^{-1}$ b.m.). We injected 1-6 times including a couple of day break [7]. In the last group (six injections), two animals passed away before the end of treatment. Untreated guinea pigs were used as controls $(n=5)$. The samples were kept on $4{ }^{\circ} \mathrm{C}$ until the experiments (approval number: BA02/2000-4/2012/).

\section{Collection and blood sample preparation}

Blood samples were collected from all animals from the peripheral vein into the Vacutainer tubes. After centrifugation at $1.600 \mathrm{~g}$ for $15 \mathrm{~min}$ at $4{ }^{\circ} \mathrm{C}$, the plasma fraction was separated from red blood cells. Native plasmas and red blood cells were stored at $4{ }^{\circ} \mathrm{C}$ until DSC measurement.

\section{DSC measurements}

The thermal denaturation of the samples was performed by SETARAM Micro DSC-II calorimeter between 0 and $100{ }^{\circ} \mathrm{C}$. The heating rate was $0.3 \mathrm{~K} \mathrm{~min}^{-1}$, and conventional Hastelloy batch vessels were used with $850 \mu \mathrm{L}$ sample volume in average. Reference sample was normal saline $(0.9 \%$
$\mathrm{NaCl})$. The repeated scan of denatured sample was used for baseline correction, which was subtracted from the original DSC curve. With the help of a two-point setting, SETARAM peak integration calorimetric enthalpy was calculated from the area under the heat absorption curve, and then the results (denaturation or melting temperature $\left(T_{\mathrm{m}}\right)$ and calorimetry enthalpy $\left(\Delta H_{\text {cal }}\right)$ normalized on sample mass) were compared.

\section{Results}

The consequence of dose-depending effect of cyclophosphamide treatment for plasma after thermal denaturation can be seen in Fig. 1. The shift of main melting temperature (except of 1 treatment), the decrease of maximum heat flow can it demonstrate (for the sake of better demonstration of the trend in the severity of the treatment we plotted only the effect in case of 1-3-5 treatments).

The scans are not symmetrical because the different plasma compounds represent different thermal domains. It is expedient to deconvolute them with Gaussian curves, so that the sum of their areas within the measurement error produces the calculated calorimetric enthalpy. In the literature, it is widely accepted that the next melting temperatures can be assigned to the main plasma compounds in case of healthy sample (see Fig. 2): $T_{\mathrm{m}} s 1 \mathrm{st} \sim 50^{\circ} \mathrm{C}$ is assigned to fibrinogen, 2 nd $\sim 62{ }^{\circ} \mathrm{C}$ to albumin, $3 \mathrm{rd} \sim 70{ }^{\circ} \mathrm{C}$ to immunoglobulins (Ig), 4 th $\sim 76{ }^{\circ} \mathrm{C}$ to protein $\mathrm{C} 3, \operatorname{IgA}, \operatorname{IgG}$ and albumin's minor, while 5 th $\sim 82^{\circ} \mathrm{C}$ significantly to $\mathrm{IgG}$ and

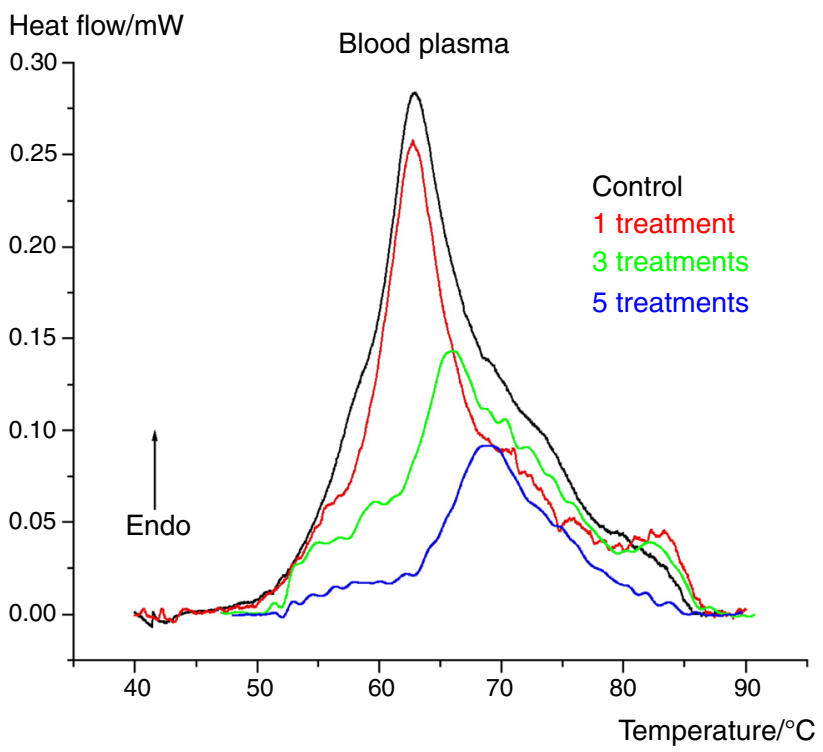

Fig. 1 The heat flow curves of plasma samples during denaturation after different treatments (curves are averages of five experiments, endotherms directed upwards) 

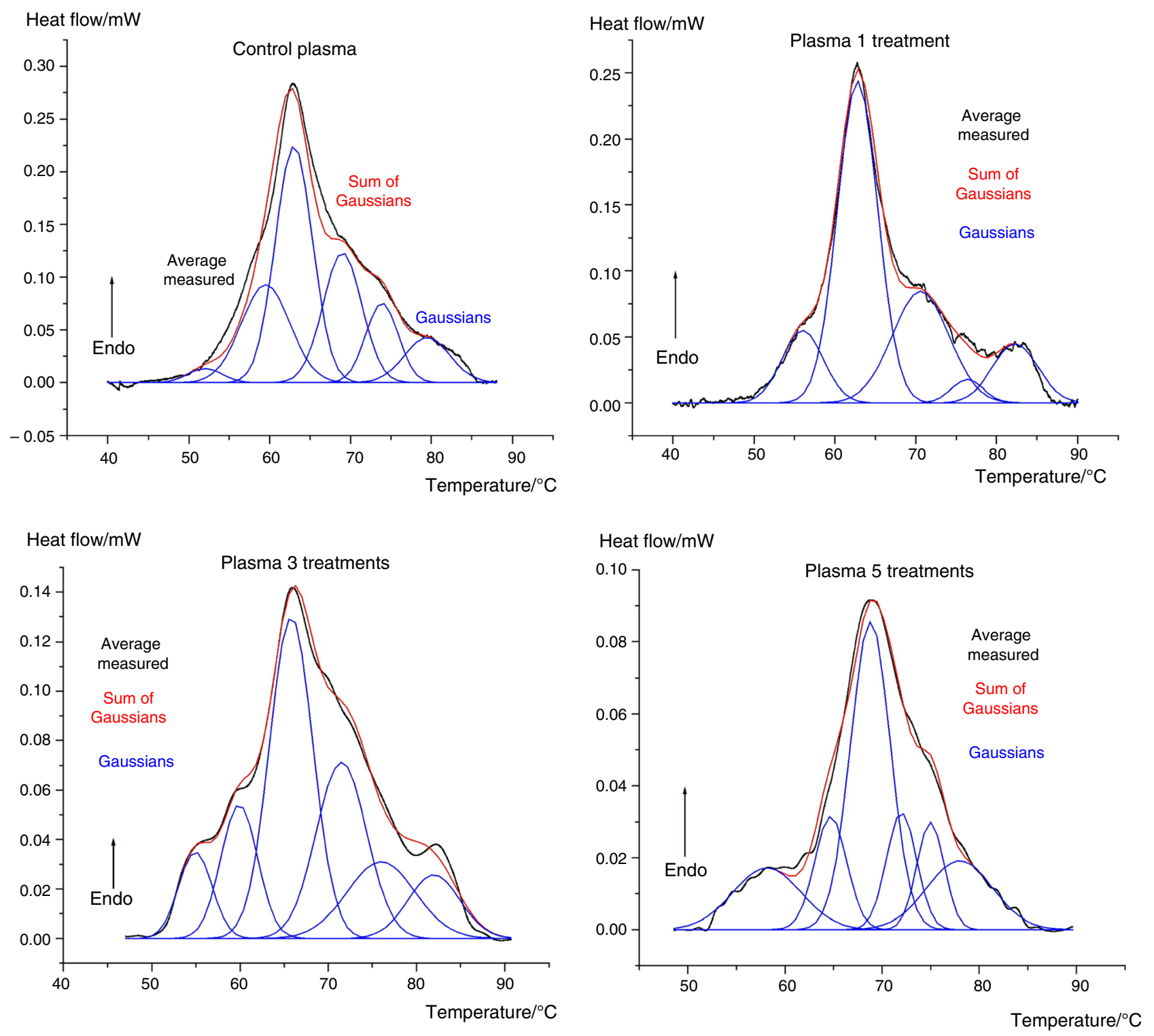

Fig. 2 Deconvoluted average heat flow curves of blood plasma with Gaussians (control, 1 treatment, 3 and 5 treatments). The more influenced compound is albumin (highest peak in $63-68{ }^{\circ} \mathrm{C}$ range)

transferrin [26-32]. In case of different treatments or diseases, shift in these values can monitor the given status. In our deconvolution procedure, we wanted to achieve the best fitting, and this way some compound which has less than 5\% contribution in calorimetric enthalpy can be ignored during the interpretation of data.

In case of denaturation of red blood cell (rbc) suspension, we were surprised to detect a four steps transition in case of control sample (see Fig. 3).

This highest transition peak is shifting to lower level with increased number of treatment (control and 1 treatment $\sim 85,3$ treatments $\sim 76$ and after 5 treatments $\sim 72{ }^{\circ} \mathrm{C}$ ), and at a first sight from the fifth injection practically remains only one endotherm. The higher three endotherms of the first group (1 injection and next day termination) decreased significantly. The calorimetric enthalpy also exhibited a significant decrease, which was more definite in the function of the time elapsed till the exit. At first look, we present at least three different thermal structural units in all cases which are proved by the deconvolution (see Fig. 4). The more effected compounds are the second and third transitions. The calorimetric enthalpy decreased 


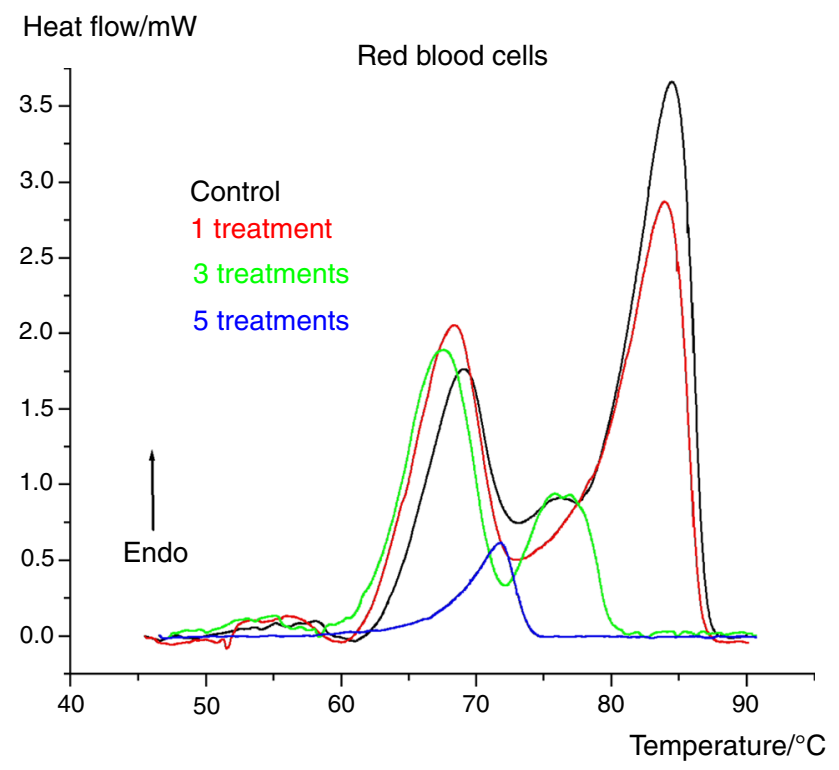

Fig. 3 Denaturation heat flow scans in case of the Guinea pig's blood cell samples. DSC scans are averages, and endotherm transition is directed upwards

significantly only from the second treatment. From the third injection appeared significant decrease in the melting temperatures and calorimetric enthalpies.

\section{Discussion}

According to our results it can be stated that the applied antitumor treatment in our animal model-medical intervention was similar to the human protocol—made significant and by DSC detectable changes in plasma and red blood cells. These changes may correlate with the concentration of drug and with the evoked biological effects in the plasma compounds and in the membrane of red blood cells. In biology and in any living system, the structural change should cause functional alterations. We can suppose that the changes caused by the side effects have an important role, therefore detecting the degree of the alteration's severity may be predictive for the patients. While the relative fast and informative determination of cyclophosphamide concentration in the plasma is difficult in clinical routine, the application of this method could be promising. Using deconvolution of average DSC scans, the next main effects of cyclophosphamide can be identified (see Fig. 2): the denaturation peak of fibrinogen from the control $52{ }^{\circ} \mathrm{C}$ shifts to $58.5^{\circ} \mathrm{C}$, the albumin from 63 to $69^{\circ} \mathrm{C}$ and the contribution of $I g G$ and transferrin appear at the control $\sim 80^{\circ} \mathrm{C}$, after the first treatment jumps to $82{ }^{\circ} \mathrm{C}$, while from the fifth treatment, it falls to $78^{\circ} \mathrm{C}$.
These findings fit well to the result of Garbett et al. [33], that is the main events caused either by a disease or a treatment will significantly influence the denaturation of plasma in the 60-80 ${ }^{\circ} \mathrm{C}$ temperature range.

The accurate prognosis of cyclophosphamide's side effects has got an important role and may correlate with the degree and quality of induced effects on blood components too. The manifestation of the treatment's effect during the denaturation of red blood cells is interesting (see Fig. 4). The mild denaturation in temperature range $50-60{ }^{\circ} \mathrm{C}$ comes from the elastic membrane compounds of rbc. The shape of DSC scan after one treatment is similar to the control one $\left(T_{\mathrm{m}} s\right.$ are $\sim 68$ and $\left.\sim 84{ }^{\circ} \mathrm{C}\right)$. The temperature of transition peaks 1 and 3 unchanged, but the calorimetric enthalpy of contribution 1 increases, in case 3 , decreases, and in case 2 , is unchanged. The most characteristic effect of cyclophosphamide starts with the third treatment. The denaturation peak around $75^{\circ} \mathrm{C}$ disappears, the other two main transition temperatures shift to 67 and $76{ }^{\circ} \mathrm{C}$, with significantly decreased calorimetric enthalpies. After the fifth injection, the structure of rbc exhibits strong cooperativity (the half width of the scan becomes very narrow). This can mean that the previous three separable thermal domains of the cell achieved a strongly ordered, less flexible structure. This can cause a severe problem in the blood circulation affecting the heart. It has been reported for more than 40 years ago that cyclophosphamide, an alkylating agent, can cause severe, or even fatal, cardiac effects in case of bone marrow transplantation $[34,35]$. The pathogenesis of cyclophosphamideinduced cardiomyopathy is based on the proliferation of free radicals and reduction of antioxidants [36]. Cyclophosphamide metabolites cause oxidative stress and direct capillary endothelial damage, resulting in extravasation of proteins, red blood cells and toxic metabolites, severely damaging the heart muscle. In myocardium, microthrombus, interstitial bleeding and edema occur. During the dissection, capillary-level micro thrombi, fibrin deposition in the enlarged heart muscle interstitium, are characteristic of cyclophosphamide-induced cardiomyopathy [37, 38].

Further investigations are wanted to support these results, e.g., applying other anticancer medicines. The application of DSC in this field of medicine seems to be fruitful, especially in that case when the TA equipment producers develop sensitive (from medical point of view) and robotic devices. It would be urgent because the clinical application of DSC in other areas is in progress, and the number of publications in this field are growing. 

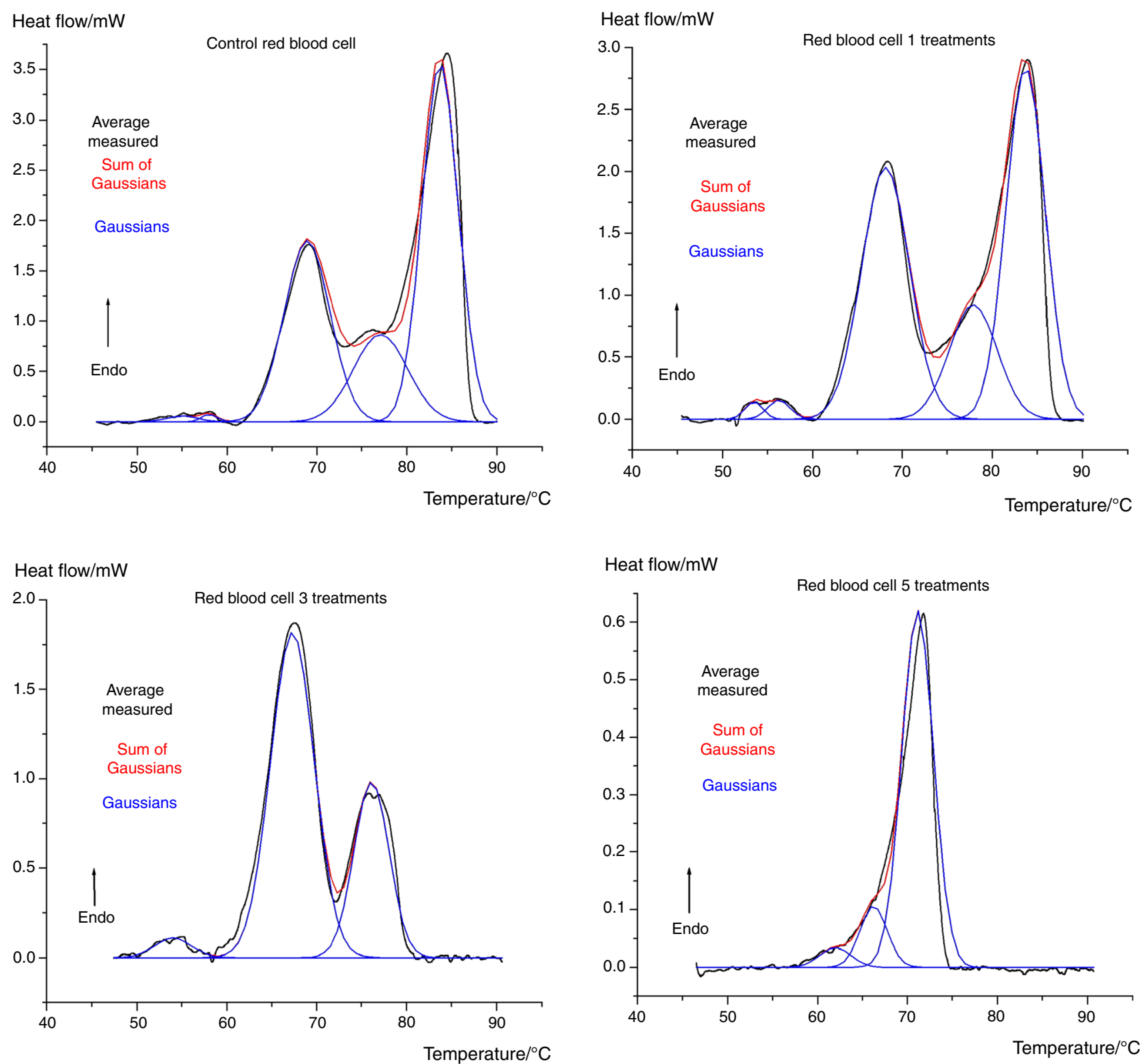

Fig. 4 The temperature dependence of denaturation in case of treated red blood cells demonstrated by the deconvolution (control, 1 treatment, 3 and 5 treatments)

\section{Conclusions}

Our recent results can also demonstrate that the alterations in the biological systems caused by any medical intervention can be detected by DSC and this way we get new possibilities in detection and prognosis of expected and unwanted effects of any treatment. Clinical application of DSC remains in progress, and it looks promising so we can obtain new useful and valuable testing procedures by further studies.

Acknowledgements Open access funding provided by University of Pécs (PTE). This work was supported by Grants OTKA CO-272 (for D.L).
Open Access This article is distributed under the terms of the Creative Commons Attribution 4.0 International License (http://creativeco mmons.org/licenses/by/4.0/), which permits unrestricted use, distribution, and reproduction in any medium, provided you give appropriate credit to the original author(s) and the source, provide a link to the Creative Commons license, and indicate if changes were made.

\section{References}

1. WHO Model List of Essential Medicines. April 2015; http://www. who.int/selection_medicines/committees/expert/20/EML_2015_ FINAL_amended_JUN2015.pdf?ua=1. 
2. Kanno TYN, Sensiate LA, de Paula NA, Sparça Salles MJ. Toxic effects of different doses of cyclophosphamide on the reproductive parameters of male mice. Braz J Pharm Sci. 2009;45:313-9.

3. Santos GW, Sensenbrenner LL, Burke PJ, Mullins GM, Blas WB, Tutschka PJ. The use of cyclophosphamide for clinical marrow transplantation. Transpl Proc. 1972;4:559-64.

4. Mills BA, Roberts RW. Cyclophosphamide-induced cardiomyopathy: a report of two cases and review of the English literature. Cancer. 1979;43:2223-6.

5. Taniguchi I. Clinical significance of cyclophosphamideinduced cardiotoxicity. Intern Med. 2005;44:89-90.

6. McDonald GB, Slattery JT, Bouvier ME, Ren S, Batchelder AL, Kalhorn TF, Schoch HG, Anasetti C, Gooley T. Cyclophosphamide metabolism, liver toxicity, and mortality following hematopoietic stem cell transplantation. Blood. 2003;101:2043-8.

7. Farkas P, Könczöl F, Lôrinczy D. Examination of the blood plasma and red blood cells in cyclophosphamide monotherapy with DSC in animal models. J Thermal Anal Calorim. 2017;127:1239-43.

8. Farkas PL, Lőrinczy D. New possibilities of application of differential scanning calorimetry, new clinical diagnostic methods on the horizon? Temperature. 2017;4(2):120-2.

9. Fonyó A, editor. The book of medical physiology [Az orvosi élettan tankönyve]. Budapest: Medicina Könyvkiadó; 1999 (in Hungarian).

10. Joy MS, La M, Wang J, Bridges AS, Hu Y, Hogan SL, Frye RF, Blaisdell J, Goldstein JA, Dooley MA, Brouwer KLR, Falk RJ. Cyclophosphamide and 4-hydroxycyclophosphamide pharmacokinetics in patients with glomerulonephritis secondary to lupus and small vessel vasculitis. Br J Clin Pharmacol. 2012;74:445-55.

11. Garbett NC, Mekmaysy CS, DeLeeuw L, Chaires JB. Clinical application of plasma thermograms. Utility, practical approaches and considerations. Methods. 2015;76:41-50.

12. Moezzi M, Fekecs T, Zapf I, Ferencz A, Lőrinczy D. Differential scanning calorimetry (DSC) analysis of human plasma in different psoriasis stages. J Therm Anal Calorim. 2013;111:1801-4.

13. Moezzi M, Ferencz A, Lőrinczy D. Evaluation of blood plasma changes by differential scanning calorimetry in psoriatic patients treated with drugs. J Therm Anal Calorim. 2014;116:557-62.

14. Könczöl F, Wiegand N, Nöt LG, Lôrinczy D. Examination of the cyclophosphamide induced polyneuropathy on Guinea pig sciatic nerve and gastrocnemius muscle with differential scanning calorimetry. J Thermal Anal Calorim. 2014;115:2239-43.

15. Lórinczy D. The "Green Issue" of JTAC as a great idea of Judit Simon. J Thermal Anal Calorim. 2015;120:13-22.

16. Michnik A. Blood plasma, serum and serum proteins microcalorimetric studies aimed at diagnosis support. In: Lőrinczy D, editor. Thermal analysis in medical application. Budapest: Akadémiai Kiadó; 2011. p. 171-90.

17. Zapf I, Fekecs T, Ferencz A, Tizedes G, Pavlovics G, Kálmán E, Lőrinczy D. DSC analysis of human plasma in breast cancer patients. Thermochim Acta. 2011;524:88-91.

18. Ferencz A, Fekecs T, Lőrinczy D. Differential scanning calorimetry, as a new method to monitor human plasma in melanoma patients with regional lymph node or distal metastases. In: Xi Y, editor. Skin cancer overview. London: InTech; 2011. p. 141-51.

19. Fekecs T, Zapf I, Ferencz A, Lőrinczy D. Differential scanning calorimetry (DSC) analysis of human plasma in melanoma patients with or without regional lymph node metastases. J Therm Anal Calorim. 2012;108:149-52.

20. Todinova S, Krumova S, Gartcheva L, Robeerst C, Taneva SG. Microcalorimetry of blood serum proteome: a modified interaction network in the multiple myeloma case. Anal Chem. 2011;83:7992-8.

21. Krumova S, Rukova B, Todinova S, Gartcheva L, Milanova $\mathrm{V}$, Toncheva D, Taneva SG. Calorimetric monitoring of the serum proteome in schizophrenia patients. Thermochim Acta. 2013;572:59-64.

22. Zs Szalai, Molnár TF, Lőrinczy D. Differential scanning calorimetry (DSC) of blood serum in chronic obstructive pulmonary disease (COPD) a new diagnostic tool ahead? J Thermal Anal Calorim. 2013;113:259-64.

23. Zs Szalai, Molnár FT, Lőrinczy D. Role of differential scanning calorimetry (DSC) in the staging of COPD: a new approach to an old definition problem. J Thermal Anal Calorim. 2017;127:1231-8.

24. Zhang J, Tian Q, Zhou SF. Clinical pharmacology of cyclophosphamide and ifosfamide. Curr Drug Therapy. 2006;1:55-84.

25. Turner PV, Brabb T, Pekow C, Vasbinder MA. Administration of substances to laboratory animals: routes of administration and factors to consider. J Am Assoc Lab Anim Sci. 2011;50(5):614-27.

26. Garbett NC, Miller JJ, Jenson AB, Chaires JB. Calorimetry outside the box: a new window into the plasma proteome. Biophys J. 2008;94:1377-83.

27. Garbett NC, Mekmaysy C, Helm CV, Jenson AB, Chaires JB. Differential scanning calorimetry of blood plasma for clinical diagnosis and monitoring. Exp Mol Pathol. 2009;86:186-91.

28. Michnik A, Drzazga Z, Michalik K, Barczyk A, Santura I, Sozanska E, Pierzchała W. Differential scanning calorimetry study of blood serum in chronic obstructive pulmonary disease. J Therm Anal Calorim. 2010;102:57-60.

29. Todinova S, Krumova S, Gartcheva L, Robeerts C, Taneva SG. Microcalorimetry of blood serum proteome: a modified interaction network in the multiple myeloma case. Anal Chem. 2011;83:7992-8.

30. Todinova S, Krumova S, Kurtev P, Dimitrov V, Djongov L, Dudunkov Z, Taneva SG. Calorimetry-based profiling of blood plasma from colorectal cancer patients. Biochim Biophys Acta. 2012;1820:1879-85.

31. Tenchov B, Abarova S, Koynova R, Traikov L, Tancheva L. Lowtemperature exothermic transitions in brain proteome of mice, effect of scopolamine. Thermochim Acta. 2017;650:26-32.

32. Tenchov B, Abarova S, Koynova R, Traikov L, Dragomanova $S$, Tancheva LA. New approach for investigating neurodegenerative disorders in mice based on DSC. J Therm Anal Calorim. 2017;127:483-6.

33. Garbett NC, Mekmaysy CS, DeLeeuw L, Jonathan B, Chaires JB. Clinical application of plasma thermograms. Utility, practical approaches and considerations. Methods. 2015;76:46-50.

34. Santos GW, Sensenbrenner LL, Burke PJ, et al. The use of cyclophosphamide for clinical marrow transplantation. Transpl Proc. 1972;4:559-64.

35. Mills BA, Roberts RW. Cyclophosphamide-induced cardiomyopathy: a report of two cases and review of the English literature. Cancer. 1979;43(6):2223-6.

36. Taniguchi I. Clinical significance of cyclophosphamideinduced cardiotoxicity. Intern Med. 2005;44(2):89-90.

37. Asiri YA. Probucol attenuates cyclophosphamide-induced oxidative apoptosis, p53 and Bax signal expression in rat cardiac tissues. Oxid Med Cell Longev. 2010;3(5):308-16.

38. Dhesi S, Chu MP, Blevins G, Paterson I, Larratt L, Oudit GY, Kim DH. Cyclophosphamide-induced cardiomyopathy: a case report, review, and recommendations for management. J Investig Med High Impact Case Rep. 2013. https://doi.org/10.1177/2324709613 480346.

Publisher's Note Springer Nature remains neutral with regard to jurisdictional claims in published maps and institutional affiliations. 